\section{Inner floor of the Rift Valley : first submersible study}

- The Rift Valley of the Mid-Atlantic Ridge ${ }^{1}$, within which lies a segment of the accretıng plate boundary between Africa and North America, is well defined between $36^{\circ} 40^{\prime} \mathrm{N}$ and $36^{\circ} 55^{\prime} \mathrm{N}$. It is about $30 \mathrm{~km}$ wide and $1.5 \mathrm{~km}$ deep in that area (Fig. 1). This small portion of the rift, WSW of the Azores, was chosen as the primary target of the FrenchAmerican Mid-Oceanic Undersea Survey (FAMOUS) programme, and many surface ship studies have been conducted already. We report here preliminary results of seven dives into the deepest part of the Rift Valley that were made by the bathyscaphe Archimede during the summer of 1973. .....

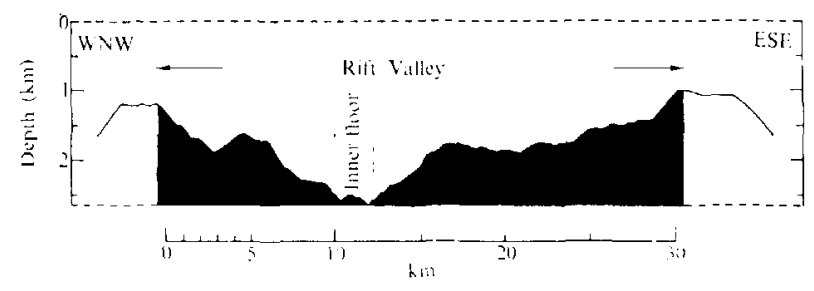

Fig. 1 Topographic cross section of the Rift Valley near $36^{\circ} 50^{\prime} \mathrm{N}$, based on surface ship data ${ }^{2}$, showing the setting of the Inner Floor in the area of the Archimede dives (Fig. 2).

Needham and Francheteau ${ }^{2}$ showed that, in the area visited by Archimide, steep, inward facing slopes of the deepest outward tilting blocks of the Rift Valley walls bound an uneven, regionally flattish Inner Floor. The central part of this is occupied by a ridge, $200 \mathrm{~m}$ high and asymmetric along at least part of its length. The ridge, or Central High ${ }^{2}$, which we have named Mont de Vénus, is about $4 \mathrm{~km}$ long and $1 \mathrm{~km}$ wide. Two marginal topographic highs, or platforms, mapped during the course of a detailed narrow beam echo-sounding survey made by the French naval vessel d'Entrecasteaux, lie along the bottom of the bordering scarps of the Inner Floor (cv. Schrumpf, cc. Caillaud, and $V$. Renard, personal communication). The marginal highs extend further south than Mont de Vénus and may be more rectilinear in gross shape.

The width between the major bordering scarps of the Inner Floor is $3.3 \mathrm{~km}$. Assuming a mean opening rate of about $2.2 \mathrm{~cm} \mathrm{yr}^{-1}$, the Inner Floor may be entircly younger than $1.5 \times 10^{-} \mathrm{yr}$, an inference supported by the occurrence here of very fresh lavas ${ }^{2}$. All seven dives of Archimede took place within the Inner Floor, and all were concentrated in an area of less than $5 \mathrm{~km}^{2}$ near $36^{\circ} 50^{\prime} \mathrm{N}$ (Fig. 2).

The major purpose of the dives was to show that useful, detailed geological mapping of very rough deep sea terrain, such as the Inner Floor, can be undertaken from a manned submersible. It was further hoped that new evidence could be gathered, which would help to answer two important questions. First, is the surface expression of the boundary between the the two diverging lithospheric plates confined to one of the highs or deeps within the Inner Floor, or is the locus of emplacement of new crust spread over a wider zone? And second, is the structural pattern of the Inner Floor steady state or transient? With these problems in mind, an effort was made to search for evidence of tectonic activity and to establish specific associations between microtopography and lava morphologies. A close, precisely controlled look was taken at a consider- able part of Mont de Vénus, and at the eastern deep and adjacent marginal high (Fig. 2),

About $9 \mathrm{~km}$ was covered by the dives, in visual contact with the ocean floor. The position of the Archimède was known within 10-200 $\mathrm{m}$, depending on her distance from the nearest of the acoustic transponders that were moored to the bottom and used for navigation. The transponder network for positioning Archimède was tied, with an accuracy of about $50 \mathrm{~m}$, to the networks used by the d'Entrecastcaux in the making of the detailed surface-ship map that was used as a base for the dives. The scale of features that could be resolved $(0-20 \mathrm{~m})$ is clearly beyond the reach of surface-ship, or even deep-towed, instrumentation. A downward looking sonar and a pressure gauge were used to measure the altitude and relative depth of Archimède respectively. These were recorded every $10 \mathrm{~s}$ on digital printouts, and the precision was about $1 \mathrm{~m}$. Useful complementary information was provided by a panoramic sonar device with a maximum range of $1,400 \mathrm{~m}$. A dual system of still and television cameras (which kept film and vidcotape recordings) gave good images of the sea floor, whether it was flattish or very steep; the usual distance of observation was 3-5 $\mathrm{m}$, and the maximum distance about $10-15 \mathrm{~m}$. A telemanipulated grab was used for sampling and four pillow fragments, together with small quantities of sediment, were collected during the course of the dives.

Mont de Vénus is largely covered by recent lava flows. It is a lenticular structure with apparent dextral offsets. Above a water depth of $2,560 \mathrm{~m}$ its summit is less than about $500 \mathrm{~m}$ wide and deepens progressively northwards (Fig. 2). The surface of the summit is characterised by large (approximately $1 \mathrm{~m}$ ) globular (dome like) lava forms (Fig. $3 a$ ) partially immersed in pale, carbonate-rich sediment. The globular structures may represent the surface expression of the top of a gently dipping, coherent lava flow unit (J. G. Moore, personal communication). The sediment may be thin, but it occupies up to $80 \%$ of the fields of view from the bathyscaphe. No large open fissures, nor any definite indications of small fissures, were seen. On the crest of the summit, relatively gentle slopes are distributed over a width of $50 \mathrm{~m}$, and the organisation of lava flows shows that the crest coincides with the dividing line between eastern and western sets of flows, both directed downslope. In addition, mapping from Archimède demonstrated that the steep south-eastern slopes of the summit of Mont de Vénus are lobate in character. The wavelength of the lobes was typically $50-100 \mathrm{~m}$.

The topography on the eastern side of Mont de Vénus down to the bordering deep is of a staircase type, with precipitous, north-south scarps, free of sediment, separating relatively flattish areas where the sediment cover is sporadic. One of the scarps is about $100 \mathrm{~m}$ high and has : slope of about $80^{\circ}$ (Fig. 2). There is also a prominent eastwest trending slope near $36^{\circ} 50^{\circ} \mathrm{N}$ (Fig. 2). Cylindrical lava forms several metres long, which we call bolsters (Fig. $3 b$ ), are present on all of the traversed scarps. The bolsters are commonly associated with shorter, phallus shaped forms which we call phalli (Fig. $3 b$ ), and with lava forms resembling entrails which we call tripe (Fig. $3 c$ ). Some of the lavas associated with the scarps suggest regular stacking. Tali of lava fragments (Fig. $3 d$ ) occur typically at the feet of the scarps; and domed or globular, and commonly striated forms, similar to those seen on the summit, are a feature of the flatter areas between scarps. Collapsed or broken pillows (Fig. 3e) and bolsters occur on the scarps and on the flatter areas. 


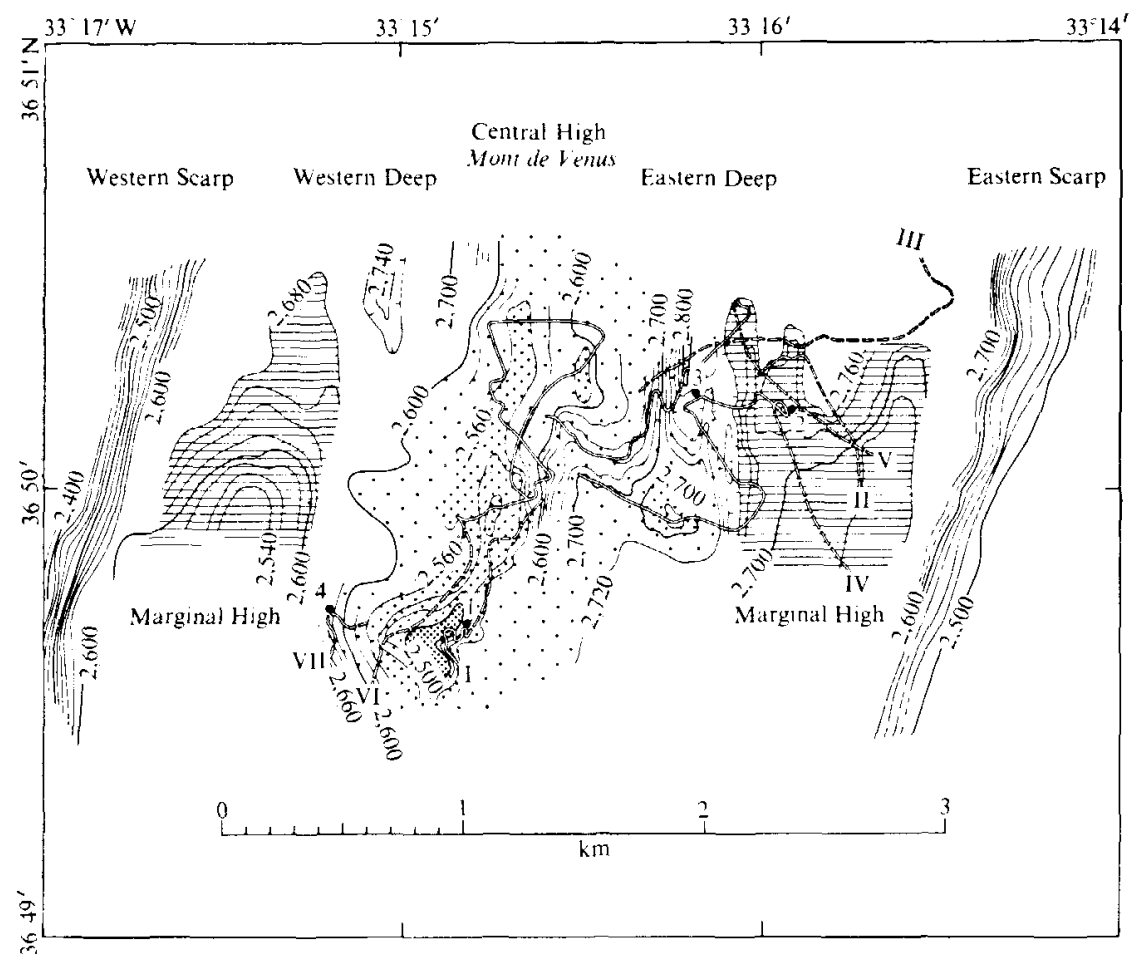

Fig. 2 Map of the Inner Floor of the Rift Valley of the MidAtlantic Ridge (Fig. 1), showing tracks of Archimede and positions of rock samples taken from Archimède. Roman numerals, Archimede. Roman numerals sequences of dives 1-7: $\bullet$, rock samples. Different ornamentation for Central High and marginal highs helps to distinguish these features. The map is based on Archimède data along tracks and other contours are sketched from the d'Entrecasteaux map. Depths shown are from pressure gauge shown are from pressure gauge measurements made from Archimede, or are normalised to this base; corrected depths recorded by precision echo-sounders from surface ships are approximately $30 \mathrm{~m}$ smaler. The averamately ing speed of the bathyscaphe was less than 1 knot when in visual contact with seafloor. The map is tied to Europe 50 coordinates. Depths are in metres. Track of Archimede: continuous double lines, visual contact with ocean floor: broken double lines, sonar contact with ocean floor.

The short section of slope crossed by the bathyscaphe on the western side of Mont de Vénus has a relatively uniform gradient and is less steep than scarps crossed on the eastern side, but it is similarly typified by bolsters which were directed downslope. Some of these reach lengths of as much as $7 \mathrm{~m}$, and many collapsed forms are present. No fields of angular boulders were seen, and sediment cover of up to $15-20 \%$ was observed.

The scarps bordering the deep to the east of Mont de Vénus follow north-south directions rather than the dominant NE-SW trend of the summit. Isolated boulders lie on a blanket of sediment on the flattish floor of the deep, and some of them are obviously detached from adjacent flow fronts. The floor of the deep is represented, at least locally, by an extremely narrow $(15-30 \mathrm{~m})$ corridor (Fig. 2)

East of the deep, a series of ridges, with a relief of about $50 \mathrm{~m}$ or more, represent northward deepening fingers of the marginal high that lies between Mont de Vénus and the major eastern scarp of the Inner Floor. The topographic grain of the eastern region seems to be more linear than that near the summit of Mont de Vénus. Slopes of the eastern ridges, however, are similarly covered by coherent lavas, including elongated forms which are directed downslope; the measured flow directions are predominantly north-west to west on the westward facing slopes, and mainly east on the eastward facing slopes. Sediment cover, locally prominent in the flatter areas, is sparse on the slopes which represent the inner edge of the eastern marginal high. There is appealing local evidence, along these slopes, of a north-south, probably normal, fault with a $2-3$ $m$ throw (Fig. $3 d$ ).

The four pillow fragments collected by Archimède come from very well known positions (Fig. 2) and, although not sampled from outcrops, they are evidently derived from adjacent flows. The rocks vary in size from $20-40 \mathrm{~cm}$ in diameter, and weigh $15-47 \mathrm{~kg}$. They are well jointed, have glassy selvages in various states of preservation and are similar, in mineralogy and chemistry, to other rocks from the Mid-Atlantic Rift Valley.
Samples ! and 4 from Mont de Vénus are olivine tholeiites with olivine crystals set in a matrix containing olivine, plagioclase and traces of spinel. Sample 2, an aphanitic pyroxene tholeiite from east of the eastern deep, is made up of equal amounts of plagioclase and clinopyroxene. Sample 3 , a picritic basalt from the eastern depression itself, contains abundant, large olivine crystals set in a groundmass of plagioclase laths, olivine and a dark mesostasis: minor spinel is present both within the olivine. or as isolated crystals. The two Mont de Vénus tholeiites are more mafic, with higher $\mathrm{MgO}(10 \%)$, and lower $\mathrm{TiO}_{2}(0.8-0.9 \%)$ and $\mathrm{K}_{2} \mathrm{O}(0.15-0.2 \%)$ content than the tholeite sampled further east $(6.4 \% \mathrm{MgO} ; 1.6 \% \mathrm{TiO} ;$ and $0.4 \% \mathrm{~K} \mathrm{O})$. The most mafic of all four sediments is the picritic basalt (sample 3) which contains $22.6 \% \mathrm{MgO}, 0.5 \% \mathrm{TiO}$ and $0.06 \% \mathrm{~K}_{2} \mathrm{O}$ ( $\mathrm{P}$. Cambon, personal communication).

The four specimens show different degrees of surface weathering. Using the thickness of manganese $e^{4}$ and palagonite $^{5}$ as indicators, and assuming a mean manganese accumulation rate of $3 \mu \mathrm{m}$ per $10^{3} \mathrm{yr}$, suggests that all of the samples are younger than about $10^{5} \mathrm{yr}$. The youngest rocks are the two samples from Mont de Vénus; these are younger than $10^{4} \mathrm{yr}$. Sample 3 from the eastern depression is at least twice as old and sample 2 at least three times as old. The data thus suggest the possibility that the age of the Inner Floor increases eastwards from Mont de Vénus.

The results of the dives, taken together, lead to some general conclusions. Steep, and very steep $\left(80-90^{\circ}\right)$, major slopes of the Inner Floor near $36^{\circ} 50^{\prime} \mathrm{N}$ are associated with bolsters which are in a downslope direction and other elongated and blunt ended lava forms. Lava talus is clearly associated with the feet of the scarps. Globule (dome) shaped, and commonly striated pillows lie more or less buried in sediments on flattish areas between scarps. Incipient break-up of many of the intact lava forms is indicated by jointing and cracking.

The lobate structures and the distribution pattern of lava forms on scarps and slope surfaces indicate that Mont de Vénus is a constructional volcanic feature, with the corollary that its major scarps are the fronts of one or more 

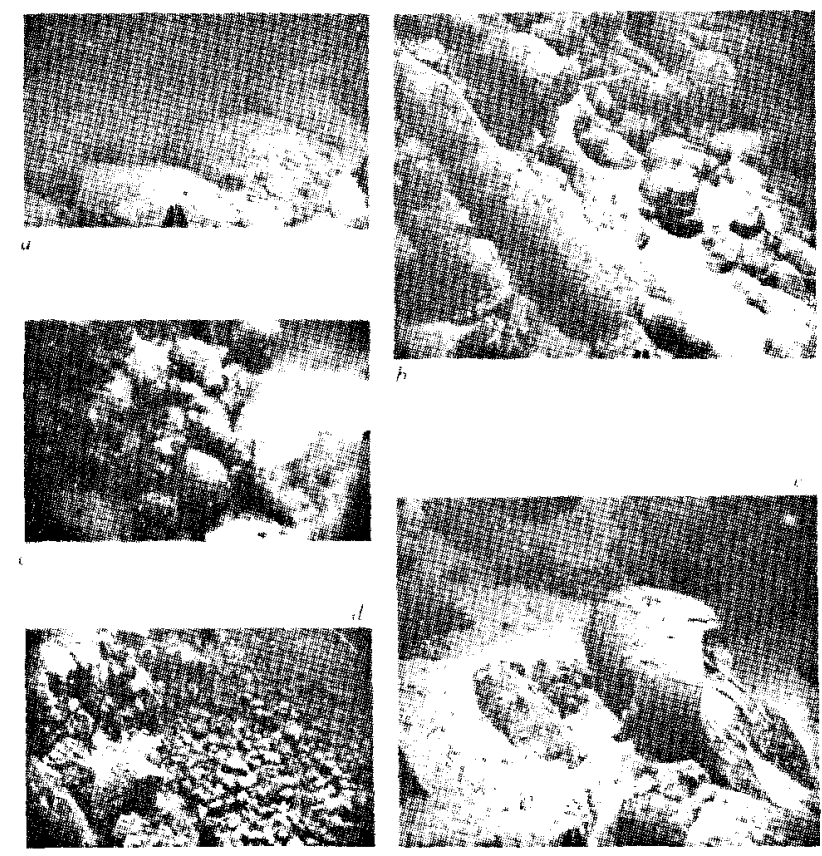

Fig. 3 Different types of lava morphologies on the Inner Floor of the Rift Valley, mapped from the bathyscaphe. $a$ Globules, partially immersed in sediment; particularly characteristic of flat and gently dipping areas. Photograph taken on summit of Central High, $b$, Bolsters and shorter blunt ended forms (phalli); directed downslope; typically found on several steep and very steep slopes where sediment cover is absent or sporadic; note cracked glassy selvages and longitudinal striae. Photograph taken on western slope of castern marginal high. $c$, Tripe, frequently associated with, or occurring on, other lava forms found on slopes. Photograph taken on western part of eastern marginal high. d. Talus of well jointed lava fragments at foot of steep, probably faulted scarp: in general, sediment-free talus is typical of feet of steep slopes including those covered by lava forms which are directed downslope. Photograph taken on western slope of eastern marginal high. e, Pillow, broken egg structure and frozen lava flow; similar isolated lava forms lie commonly on less steep parts of slopes and on flattish areas where sediment cover is relatively abundant. Photograph taken on western edge of eastern marginal high.

flow units. It is, nevertheless, possible that flows which are directed downslope mask evidence of vertical movements that have contributed to the process which formed the scarp. Such an interpretation would be consistent with the steepness of the scarps and with the partially demonstrated bilateral asymmetry of Mont de Vénus. The apparently straighter trend of structures east of the eastern deep which flanks Mont de Vénus, and the local evidence of faulting along the inward facing slopes of the eastern deep, point rather more persuasively to some tectonic influence between the faulted scarps that border the Inner Floor. Indeed, the mapped part of the eastern deep near $36^{\circ} 50 \mathrm{~N}$ may be a tensional fissure and the volcanic activity reflected by the downslope flows east of the eastern deep may be associated with dilation and small scale vertical movements.

The observation that the two rocks sampled from Mont de Vénus are younger than those sampled further east suggests, in a tentative way, that Mont de Vénus is the youngest part of the Inner Floor. The dominant, and approximately central position of Mont de Vénus within the Inner Floor adds some weight to this inference, as does the limited evidence that the relief of the marginal highs has been more subject to modification by vertical movements than that of Mont de Vénus itself. It seems, therefore, quite possible, although young lavas are found over a considerable part of the width of the Inner Floor, that Mont de Vénus represents the most recent surface expression of new crust along the plate boundary.

We acknowledge the invaluable contributions of the Archimède pilots (cc. de Froberville, 1v. de Guillebon, lv. Harismendy) and engineers (J. L. Michel, D. Semac); the assistance of officers, technicians and crew on board the French Navy ship Marcel Le Bihan; and the support of C. Riffaud. We thank V. Renard; J. Phillips, J. Moore and other members of the US Scientific group of the FAMOUS programme; $\mathrm{M}$. Mattauer and $\mathrm{P}$. Tapponier.

G. Bellaiche

J. L. Cheminee

Centre National de la Recherche Scientifique,

Paris, France

\section{J. Francheteau \\ R. Hekinian \\ X. Le Pichon \\ H. D. NeEdHam}

Centre Oceanologique de Bretagne,

Brest, France

\section{R. D. Ballard}

Woods Hole Oceanographic Institution, Woods Hole, Massachusetts 02543

Received March 29; revised April 24, 1974.

${ }^{1}$ Heezen, B. C., Tharp, M., and Ewing, M., Spec. Pap. geol. Soc. Am., 65, 122 (1959).

2 Needham. H. D.. and Francheteau, J., Earth planet. Sci. Lett., 22, 29-43 (1974).

${ }^{3}$ Muir, I. D. Tilley, C. E., and Scoon, J. S., J. Petrology, 7, 193 201 (1966)

4 Bender, M. L., Ku, T.L., and Broecker, W. S., Science, 151, 325-328 (1966); Earth planet. Sci. Lett., 8, 143-148 (1970).

' Moore, J. G., Prof. Pap. US geol. Surv., 550, 163-171 (1966). 